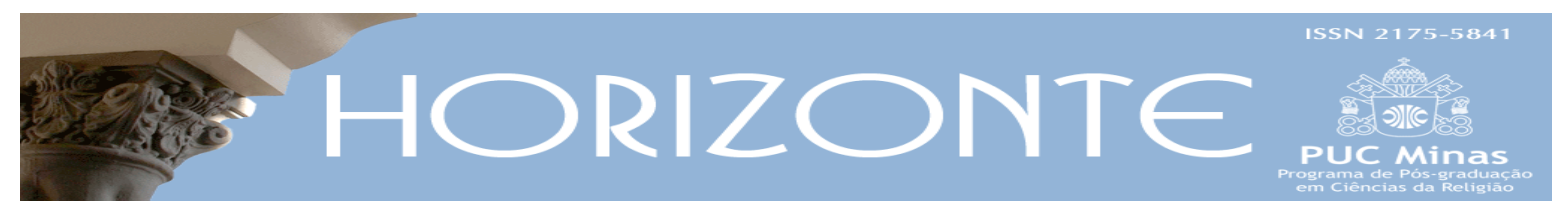

Dossiê: Narrativas Sagradas e Linguagens Religiosas - Artigo Original ๑。 DOI - 10.5752/P.2175-5841.2016v14n42p452

\title{
Narrativas de curas e exorcismos de Jesus: uma expressão da linguagem religiosa
}

\author{
Narratives of healings and exorcisms of Jesus: \\ An expression of religious language
}

João Luiz Correia Júnior*

\begin{abstract}
Resumo
As narrativas de curas e exorcismos de Jesus ocupam lugar de destaque nos Evangelhos e, de modo especial, no Evangelho de Marcos. Esses relatos escritos têm por base tradições orais, comuns do ambiente do Mar Mediterrâneo, em que havia grande familiaridade com curandeiros, exorcistas e taumaturgos. Além disso, na Palestina do tempo de Jesus, primeira metade do século I, havia grande expectativa messiânica e apocalíptica; Deus estaria prestes a revelar sua face misericordiosa, enviando finalmente o Messias, capaz de restaurar a dignidade do povo de Israel. Nesse contexto, não tardou para que as ações e as palavras de Jesus fossem interpretadas como as de um taumaturgo que, gradativamente, vai sendo proclamado como o Messias esperado. Tendo presente todos esses elementos, o objetivo deste artigo é demonstrar que as narrativas de curas e exorcismos de Jesus podem ser interpretadas como expressão da linguagem religiosa de tradição judaica, que serviu de base para os respectivos textos encontrados nos Evangelhos, fundamentos da cultura religiosa cristã.
\end{abstract}

Palavras-chave: Religião; Judaísmo; Cristianismo; Movimento de Jesus; Hermenêutica bíblica.

\begin{abstract}
The healings and exorcisms narratives of Jesus are in the Gospels, especially in the Gospel of Mark. These written reports are based on oral traditions, common around the Mediterranean Sea. There, people had great familiarity with healers, exorcists and miracle workers. Besides, in the first half of the century at Jesus 'Palestine, there were great messianic and apocalyptic expectation; God was about to turn his merciful face, finally sending the Messiah, which could restore the dignity of the people of Israel. In this context, the actions and words of Jesus were interpreted as a miracle worker and, gradually, as the expected Messiah. This research proposes that the oral and written narratives that enhance the healing and exorcism of Jesus express the religious language of Jewish tradition, which was the foundation of Christian religious culture.
\end{abstract}

Keywords: Religion; Judaism; Christianity; Jesus movement; Biblical hermeneutics.

\footnotetext{
Artigo recebido em 29 de janeiro de 2016 e aprovado em 13 de junho de 2016.

* Doutor em Teologia (com concentração na área dos Estudos Bíblicos) pelo Programa de Pós-Graduação em Teologia da PUC-RIO. Professor do Programa de Pós-graduação em Ciências da Religião da UNICAP. País de origem: Brasil. E-mail: jota@unicap.br
}

Horizonte, Belo Horizonte, v. 14, n. 42, p. 452-472, abr./jun. 2016 - ISSN 2175-5841 


\section{Considerações iniciais}

Entre as inúmeras narrativas em torno da pessoa de Jesus, os Evangelhos dão um destaque especial às curas e exorcismos por ele realizados. A prática desse taumaturgo ${ }^{1}$, conforme está escrito, causa admiração em muitos, irradia a sua fama por toda a Galileia, e provoca irritação em lideranças daquele contexto sociorreligioso.

A pesquisa em torno dessas narrativas divide a opinião de muitos estudiosos. Por um lado, os relatos são atestados em muitas camadas antigas da tradição, que não se pode duvidar de que há algum fundo histórico. Por outro lado, tais relatos têm claros objetivos de reforçar a fé na pessoa de Jesus, como o Cristo dos tempos messiânicos, tão esperados pelo povo judeu. ${ }^{2}$

Seja como for, essas narrativas expressam uma linguagem religiosa daquela época. No contexto palestinense da primeira metade do século I, em meio às expectativas messiânicas judaicas, as narrativas orais da primeira geração dos discípulos e discípulas de Jesus, testemunham ser ele um homem de Deus, taumaturgo, com poderes de curar doentes físicos e mentais, pessoas possuídas por espíritos maléficos. Nos textos que, gradativamente, foram escritos segundo padrões de linguagem religiosa judaica, as narrativas em torno das curas e exorcismos de Jesus serviam para confirmar e propagar a fé cristã na pessoa de Jesus de Nazaré.

No presente artigo, defende-se a proposição de que as narrativas de curas e exorcismos de Jesus são expressões orais da linguagem religiosa daquele contexto sociocultural. Também configuram uma forma de expressão da linguagem religiosa

\footnotetext{
${ }^{1}$ Taumaturgo é um termo que vem do grego Өaú $\alpha$, thaûma, "milagre", "maravilha”, "prodígio", mais ع́pyov, érgon, "obra”, "trabalho". Designa alguém que realiza milagres, obras maravilhosas, prodígios, por conta de sua ligação com o divino.

2 Sobre a pesquisa realizada, desde o século XVIII, em torno das narrativas de milagres, indico o excelente artigo de Juan José Bartolomé, intitulado "Resenha da pesquisa crítica sobre os milagres de Jesus", publicado como introdução ao livro "Os milagres de Jesus: perspectivas metodológicas plurais" (BARTOLOMÉ, In: AGUIRRE (org), 2009, p. 13-50).
} 
escrita das primeiras comunidades cristãs, com o objetivo de propagar a fé em Jesus como o Cristo.

\section{Narrativas de curas e exorcismos de Jesus em suas origens}

Narrar não é somente transmitir um fato, mas contar uma experiência humana. E isso é um tanto complexo, pois a experiência humana oscila constantemente entre o subjetivo e o intersubjetivo, relacional. O subjetivo é a dimensão individual dos desejos, dos projetos, das realizações ou das frustrações de qualquer pessoa. Cada ser humano constrói (e, em parte, traz gravado) um projeto de vida que procura realizar durante sua existência. O intersubjetivo é uma vivência relacional: a) com o mundo (a natureza, a vida e o que a realidade oferece); b) com o outro indivíduo (relacionamentos próximos); c) com o grupo humano (todo ser humano está socializado, de uma forma ou de outra, em diferentes níveis: família, comunidade, trabalho, religião, etnia, nação, etc.). Tudo reúne e socializa, ou seja, o indivíduo está sempre em sociedade. Essa característica da vida humana tem uma grande influência na "socialização da experiência religiosa (CROATTO, 2001, p. 41-42).

As narrativas de curas e exorcismos, como qualquer outra narrativa, estão envoltas nessa complexa rede de relações que permeiam as subjetividades e intersubjetividades humanas. Então, o desejo de ficar curado, de ter uma pessoa da família recuperada de algum tipo de doença física e ou psíquica, ou o próprio desejo do terapeuta / taumaturgo em curar, motivado por sua missão ou por pura compaixão, tudo isso faz parte da experiência humana e, como tal, está envolvido na narrativa.

Aprofundando um pouco mais, pode-se afirmar que narrar consiste em contar uma experiência humana contextualizada. Para tanto é necessário reconstruir o mundo que emoldura o fato, um mundo com seus códigos e regras sociais; consiste em ligar ações entre si dentro de uma relação de causalidade/efeito, por meio dos componentes que formam a estrutura interna da 
narrativa. Assim, numa narrativa, encontram-se: (1) uma sucessão temporal de ações/fatos; (2) a presença de um agente-herói animado por uma intenção que leva a narrativa a seu fim; (3) um enredo que sobrepuje a cadeia das peripécias e as integre na unidade de uma mesma ação; (4) uma relação de causalidadeconsecução estruturando o enredo mediante um jogo de causa e efeito (MARGUERAT; BOURQUIN, 2009, p. 28-29).

Seguindo essa linha de raciocínio, as curas e exorcismos de Jesus surgem de narrativas orais, dentro de um contexto sociorreligioso do mundo antigo em que a determinadas pessoas (homens e mulheres de Deus) são atribuídos poderes de cura. O conteúdo dessas narrativas tem, provavelmente, um ponto de partida histórico. Para o biblista John Dominic Crossan (1994, p. 369), “Jesus era um exorcista e um curandeiro". Essa é a conclusão a que chegou também Giuseppe Barbaglio, em sua pesquisa histórica sobre Jesus, ao afirmar que "deve-se admitir que Jesus realizou algumas curas, pois senão se questionaria o dado corroborado por tantos e consideráveis testemunhos, de ter agido como curandeiro e exorcista” (BARBAGLIO, 2011, p. 247).

Curandeiros e exorcistas eram comuns no ambiente palestino daquela época, mas também em todo mundo antigo. O desejo de saúde física, o medo de doença, dor e morte são forças motrizes essenciais da ação humana. Na Antiguidade, isso causa a reação de uma respeitável medicina que se baseia em observações empíricas e desenvolve conhecimentos estupendos. Ela está ligada aos nomes de Hipócrates (século V a.C.), o expoente máximo da escola médica da ilha de Cós, e de Galeno de Pérgamo (130-200 d.C.). Mas este é apenas um lado. Deuses, heróis, milagreiros e lugares miraculosos também prometem cura. É impossível traçar linhas divisórias precisas (KLAUCK, 2011, p. 169)3 Nesse contexto, afirma Barbaglio (2011, p. 222), Jesus taumaturgo não foi um caso à parte, um fenômeno único e exclusivo. Ele se insere, com justiça e plenamente, no

\footnotetext{
${ }^{3}$ Hans-Josef Klauck, em seu livro "O entorno religioso do cristianismo primitivo I: religião civil e religião doméstica, cultos e mistérios, crença popular", apresenta um capítulo sobre "Crença popular: astrologia, adivinhação, milagre, magia" (2011, p. 167-261). Trata-se de uma temática importante por conta da significância para a compreensão do contexto sociorreligioso do movimento de Jesus.
} 
seu ambiente cultural e social, mostrando claras analogias, mas também peculiaridades inegáveis. Compará-lo com os outros taumaturgos de sua época mostra-se útil, inclusive necessário, para compreendê-lo.

A demanda por curandeiros e exorcistas é um fenômeno que aumenta nitidamente em algumas épocas e recua em outras. No tempo de Jesus estamos no auge de uma dessas demandas, por diversos fatores interligados: tensões socioeconômicas entre a cultura do campo e da cidade; crescente empobrecimento de grande contingente populacional; tensões sociorreligiosas entre judeus e não judeus; tensões entre culturas tradicionais e novas modalidades culturais, em virtude da dominação greco-romana4.

Nesse contexto de crise e de caos, movimentos de protesto e renovação surgem sob a liderança de líderes carismáticos, legitimados por pessoas das camadas excluídas que se sentem acolhidas, contempladas em suas necessidades imediatas e até curadas de suas mazelas, por meio de práticas milagrosas carismáticas. Esse fenômeno deve ser interpretado não apenas querigmaticamente "de cima para baixo”, como anúncio final da intervenção de Deus na história, mas também como expressão de um protesto humano “de baixo para cima” (THEISSEN; MERZ, 2002, p. 315), expressão da linguagem sociocultural e sociorreligiosa de um determinado momento histórico bem situado.

Em seu contexto histórico, Jesus pode ser enquadrado dentro do judaísmo carismático da Galileia do primeiro século, tendo como referencial os paralelos com outras figuras carismáticas ligadas principalmente aos taumaturgos contemporâneos a ele, tais como: Hanina bem Dosa e Honi (Onias) Há-Me’aggel. Eles atingiam a camada social mais baixa de maneira sensível e direta, de tal modo que a população acorria a eles sem os entraves da burocracia, da ortodoxia ou das autoridades superiores. Esses líderes carismáticos possivelmente possuíam,

\footnotetext{
${ }^{4}$ Dentro desse contexto de diversas tensões sociais, GERD THEISSEN e ANNETTE MERZ apresentam um excelente estudo sobre Jesus,
} como aquele que cura. Sugiro, então, a leitura de todo o capítulo 10 do livro "O Jesus histórico: um manual” (2002, p. 305-340). 
perante o povo, o poder místico de prover os camponeses galileus com um novo modelo de aproximação com Deus (SCARDELAI, 1998, p. 245-246).

É, portanto, no interior das estruturas sociais, em meio aos intricados desafios da vida cotidiana, que a experiência de fé se expressa em diversas linguagens. Como afirma Max Weber (1999, p. 279), “a ação religiosa ou magicamente motivada, em sua existência primordial, está orientada para este mundo. As ações religiosas ou magicamente exigidas devem ser realizadas 'para que vás muito bem e vivas muitos e muitos anos sobre a face da terra'”.

Assim, de acordo com o teólogo João Batista Libânio (1990, p. 35), a experiência religiosa é, na sua última radicalidade, um protesto contra o sentido ameaçador do real, do que está-aí, do estabelecido, afirmando a existência de um Sentido, antecipado na esperança, já que não se percebe no presente. Nessa linha, conclui o autor:

K. Marx intui corretamente, ainda que tire consequências equivocadas, ao afirmar que a religião é "o suspiro da criatura oprimida", é o levantar o pescoço do afogado, o erguer os olhos do sufocado, negando a água ou a fumaça envolvente, como uma situação definitiva e inexorável. A religião projeta - isto é, lança para fora - do coração do homem uma realidade de sentido, uma pátria da identidade, um reino de fraternidade e paz, que contradiz a evidência de uma sociedade caótica, alienada, sem irmãos e em guerra (LIBÂNIO, 1990, p. 35-36).

O ser humano se constitui humano precisamente ao expressar seus desejos, necessidades e sonhos de uma terra sem males, por meio da linguagem religiosa. Por isso, os surtos do sagrado religioso são protestos contra o empobrecimento, a miséria, o sofrimento, enfim, o encurtamento dos limites. A busca do sagrado religioso é fruto do desejo de empoderar-se da força, energia vital (em grego, dynamis), dinâmico poder divino, a fim de transformar a situação existencial e os fatos circunstanciais em uma realidade nova, uma sociedade - diríamos hoje, 
inclusiva - em que todos possam ter uma vida com dignidade, vida "em abundância" (Jo 10,10)5.

A expectativa da abundância, na tradição cultural do povo de Jesus, é expressa numa linguagem religiosa. Simboliza a felicidade escatológica, quando chegar a plenitude dos tempos, em que Deus estenderá sua proteção sobre todos os povos, tal como lemos no Livro do Apocalipse (7,16-17): "Nunca mais terão fome, nem sede, o sol nunca mais os afligirá, nem qualquer calor ardente; pois o Cordeiro que está no meio do trono os apascentará, conduzindo-os até às fontes de água da vida. E Deus enxugará toda lágrima de seus olhos”. Essas imagens literárias estão presentes na tradição profética do povo de Jesus, por exemplo, em Oseias e Isaías. Em Oseias $(2,20)$, lemos que, finalmente, chegará um tempo de paz e segurança: "Farei em favor deles, naquele dia, um pacto com os animais do campo, com as aves do céu e com os répteis da terra. Exterminarei da face da terra o arco, a espada e a guerra; fá-los-ei repousar em segurança”. Em Isaías (11,4), está escrito que, nesse tempo escatológico, haverá um líder animado pelo espírito de Deus, que “julgará os fracos com justiça, com equilíbrio pronunciará a sentença em favor dos pobres da terra”.

Paz tem a ver com justiça social e fartura de bens para todos, base, como sabemos, para que haja saúde física e psíquica das pessoas. Essa expectativa dos tempos messiânicos se estende do profetismo de Israel à literatura apocalíptica e, sem dúvida, permeia o contexto sociorreligioso de Jesus. O povo sofrido, sob a dominação de impérios que se sucederam, tais como Egito, Babilônia, Pérsia, Grécia, e agora Roma, em permanente crise, aspira por tempos de paz, segurança e justiça social, abundância de bens materiais para todos, a fim de que - finalmente - se possa ter vida saudável, livre das mazelas causadas pela miséria.

Como se percebe, essa linguagem religiosa nada tem de alienação, mas, pelo contrário, expressa um desejo profundo de empoderamento da força divina, por

${ }^{5}$ Neste artigo, segue-se a tradução da BÍBLIA DE JERUSALÉM - Nova edição, revista e ampliada, 2002. 
meio da fé. Como bem afirmou Libânio (1990, p. 36), "não se trata de nenhuma função compensatória ou desesperada e alienada, mas afirmação clara de ser humano".

Na época de Jesus, a expectativa dos tempos messiânicos era bastante forte. Em clima apocalíptico, esperava-se ansiosamente que, a qualquer momento, Deus se revelasse em sua divina misericórdia, por meio de sua face amorosa, libertadora, salvadora. Nesse novo tempo, finalmente, eclodiria o Reino. Os Evangelhos atestam como dado inabalável que Jesus não somente falou do Reino de Deus, mas também fez dele seu tema central, o cerne de sua pregação (BARBAGLIO, 2011, p. 261). Certamente, Jesus não foi nem o primeiro nem o único a ocupar-se do Reino de Deus no seu ambiente cultural e religioso. Mas, segundo Barbaglio (2011, p. 264), ele é o único hebreu da antiguidade conhecido que proclamou não só a iminência do tempo da libertação final, mas o início desse tempo de salvação já no presente, por meio de sua ação.

As palavras e, sobretudo, as ações taumatúrgicas de Jesus são compreendidas pelos narradores como sinais evidentes da chegada definitiva do Reino de Deus. Isso foi um fato histórico, porque teve repercussões sociais, ao ponto de causarem a morte Jesus. De acordo com o biblista Rinaldo Fabris,

Os gestos poderosos de Jesus, seja qual for a interpretação que se lhes dê, suscitam o problema da sua autoridade religiosa, reconhecida ou contestada nos meios judaicos. Jesus de Nazaré, reduzido à função de pregador religioso da moral ou de narrador de parábolas não teria causado nas massas um impacto que lograsse incomodar as autoridades religiosas e políticas responsáveis pelas instituições religiosas tradicionais e pela ordem pública na Palestina. É também por causa desses gestos poderosos e perigosamente significativos no contexto religiosos e político palestinense dos anos 30 que Jesus se tornou suspeito de heterodoxia religiosa e acabou sendo condenado como pretenso "rei dos judeus". Por isso os gestos taumatúrgicos de Jesus permanecem indissoluvelmente ligados, quer ao seu projeto histórico concebido sob o sinal do senhorio de Deus, quer à conclusão trágica da sua atividade pública (FABRIS, 1988, 154). 
Sem dúvida, no centro da mensagem de Jesus estava a fé judaica nos tempos messiânicos, em que Deus logo se revelaria definitivamente em favor do sofrido povo de Israel. ${ }^{6}$ Jesus anuncia como boa notícia a chegada do tão esperado reinado de Deus, em que seriam acolhidos, em primeiro lugar, os pobres, fracos, doentes e pecadores que mudassem de vida. Com essa mensagem, viajou pela Palestina como pregador itinerante, focando sua atenção em pequenos pontos a noroeste do Mar da Galileia. Entre pessoas simples da Galileia, pescadores e camponeses, forma um grupo de adeptos; mulheres também o seguiam. Ao mesmo tempo, Jesus atuava como carismático taumaturgo, que curava e expulsava demônios. As pessoas afluíam até ele para se beneficiar de seu dom de cura. Essas curas passaram a ser interpretadas como sinais evidentes da chegada do reinado na Deus. Provavelmente, ele oscilou (como se exprime na oração do Getsêmani) entre a experiência da morte e a esperança de que Deus ainda interviria antes de sua morte e concretizaria seu reinado. Depois de sua morte, tiveram de dar nova interpretação a todo o destino de Jesus e à sua pessoa. Reconheceram que ele era o Messias, o Cristo (THEISSEN; MERZ, 2002, p. 596 e 598).

\section{Narrativas de curas e exorcismos nos Evangelhos}

O gênero literário "evangelho", que traduz o latim evangelium, do grego euangelion, "boa nova", refere-se ao que Jesus fez e ensinou. A boa nova é, portanto, o próprio Jesus. Os textos que compõem os Evangelhos surgiram a partir de relatos orais das pessoas que conheceram Jesus de perto. Isso se aplica, sobretudo, ao Evangelho de Marcos, o texto que deu origem a esse gênero literário e serviu de base para os demais.

Os relatos de curas e exorcismos de Jesus fazem parte desse conteúdo que se convencionou chamar de "tradição oral". Essas narrativas foram colocadas por escrito a partir de um certo esquema literário que segue padrões da literatura

\footnotetext{
${ }^{6}$ No livro "Jesus, aproximação histórica", José Antonio Pagola aborda o tema das curas de Jesus no capítulo 6, que tem como título: "Curador da vida" (2010, p. 191-218). Trata-se de um resumo bem escrito, de fácil compreensão, apoiada em referências da pesquisa bíblica atual. Sugiro leitura.
} 
religiosa judaica, uma vez que as primeiras comunidades cristãs foram formadas por pessoas provenientes do Judaísmo. A seguir, apresentamos o elenco das narrativas de curas e exorcismos dos Evangelhos, procurando entender a sua estrutura interna, semelhanças e diferenças.

\subsection{Narrativas de curas}

Nos Evangelhos, segundo atesta Giuseppe Barbaglio (2011, p. 239-240), são quinze as narrativas de curas atribuídas a Jesus. Dessas quinze, oito relatos estão no Evangelho de Marcos, que foi uma das fontes utilizadas por Mateus e Lucas, segundo a Teoria das Fontes7:

Em Marcos, oito relatos de cura:

1. a sogra de Pedro (Mc 1,29-31);

2. um leproso (Mc 1,40-45);

3. um paralítico (Mc 2,1-12);

4. o homem da mão ressecada (Mc 3,1-6);

5. a mulher afetada de hemorragia crônica (Mc 5,25-34);

6. um surdo-mudo (7,31-36: não reportado por Mateus e Lucas);

7. um cego de Betsaida (Mc 8,22-26: ausente em Mateus e Lucas);

8. o cego Bartimeu (Mc 10,46-52, que tem paralelo em Mt 20,29-34, na narrativa dos dois cegos, e uma repetição em Mt 9,27-31, que é um relato próprio de Mateus).

Em Lucas e Mateus, temos apenas uma narrativa de cura que não aparece em Marcos (texto provavelmente de uma fonte comum, “Q”): o criado/menino do centurião de Cafarnaum (Lc 7,1-10; Mt 8,5-13).

\footnotetext{
7 A teoria das fontes abrange os três primeiros evangelhos, chamados "sinóticos" (porque com "um só olhar" percebe-se claramente que esboçam uma imagem de Jesus diferente da do Evangelho de João), com as fontes que os alicerçam. Assim, o Evangelho de Marcos (ou o ligeiramente revisado Dêutero-Marcos) serve de fonte para Mateus e Lucas. Ambos se utilizam ainda da Fonte dos Ditos (chamada " $Q$ ", abreviatura da palavra alemã "quelle", fonte), que pode ser reconstituída a partir deles. Além de Marcos e $Q$, Mateus e Lucas se serviram de sua própria tradição independente, oral ou escrita (THEISSEN; MERZ, 2002, p. 45).
} 
Em João, entre os sete sinais, temos três relatos de cura:

1. o paralítico da piscina de Betsaida (Jo 5,1-9);

2. o cego de nascença (Jo 9);

3. o filho do funcionário real de Cafarnaum (Jo 4,46-54; paralelo Q).

Na Fonte L (fonte própria de Lucas), temos mais três relatos:

1. a mulher encurvada (Lc 13,10-17);

2. os dez leprosos (Lc 17,11-19);

3. o hidrópico (Lc 14,1-6).

Além disso, os Evangelhos apresentam alguns sumários sobre a atividade terapêutica de Jesus:

- Mc 1,32-34, paralelo em Mt 8,16 e Lc 4.40-41;

- Mc 6,53-56, paralelo em Mt 14,34-36;

- Mt 4,23-25 e 9,35, que serve de moldura à seção dos capítulos 5 - 9;

- Mt 14,14; 19,2; 21,14, anotações sintéticas sobre a ação geral terapêutica de Jesus;

- Mt 15,29-31, em que se especifica os beneficiados das curas: "coxos, cegos, aleijados, mudos e muitos outros”.

Acrescente-se a essa lista, a resposta de Jesus aos enviados do Batista, tal como lemos em Mt 11,4-6 (paralelo em Lc 7,22-23): "Ide contar a João o que estais ouvindo e vendo: os cegos recuperam a vista, os coxos andam, os leprosos são purificados e os surdos ouvem, os mortos ressuscitam e os pobres são evangelizados”. De acordo com Barbaglio (2011, p. 240), esse trecho do Evangelho "tem grandes probabilidades de remontar ao próprio Jesus".

De um modo geral, as narrativas de curas recolhidas nos Evangelhos, seguem, mais ou menos, o seguinte esquema: 
- Introdução, na qual se expõe o caso do doente, na condição de uma pessoa já desesperançada de salvar-se com os meios terapêuticos normais.

- Encontro com o taumaturgo; ao pedido de cura correspondem o gesto e a palavra eficaz.

- Conclusão-despedida, na qual se regista a cura efetuada, bem como a reação do curado e das testemunhas (FABRIS, 1988, p. 146).

Há uma variante desse modelo na narrativa de exorcismo. Como veremos a seguir, nas narrativas de exorcismos, o encontro de Jesus com o endemoninhado se transforma numa espécie de duelo entre o taumaturgo e o espírito de possessão que, por fim, acaba vencido e expulso.

\subsection{Narrativas de exorcismos}

As narrativas de exorcismos praticados por Jesus, segundo os relatos dos Evangelhos, têm por base o Evangelho de Marcos, embora Mateus e Lucas apresentem conteúdo de suas próprias fontes. No Evangelho de João não há narrativas de exorcismos, nem sumários relativos a esse tema. (MEIER, 1998, p. 170).

O material sobre narrativas de exorcismos pode ser apresentado da seguinte forma, de acordo com Irineu J. Rabuske (2001, p. 37-39):

1) O Evangelho de Marcos é o que apresenta maior número de material narrativo. Terá narrativas semelhantes em Mateus e Lucas, uma vez que, segundo a Teoria das Fontes, esses Evangelhos tinham Marcos como texto de referência:

- Mc 1,21-28, paralelo em Lc 4,33-37): o endemoninhado na sinagoga;

- Mc 5,1-20, paralelo em Mt 8,24-34 e Lc 8,26-39: o endemoninhado geraseno;

- Mc 7,24-30, paralelo em Mt 15,21-28: a filha da mulher siro-fenícia;

- Mc 9,14-29, paralelo em Mt 15,21-28: o menino epilético; 
2) Em Marcos, encontramos sumários das atividades exorcistas de Jesus que aparecem também em Mateus e Lucas, de forma livre:

- Mc 1,34, paralelo com Mt 8,16b e 4,40b-41;

- Mc 4,23, paralelo com Mt 1,39 e 4,44;

- Mc 3,11, sem paralelos.

3) Os Evangelhos de Mateus e Lucas apresentam um breve relato de exorcismo e uma parábola, que ambos extraem de uma fonte comum diferente de $\operatorname{Marcos}(\mathrm{Q})$.

- Mt 9,32-34; 12,22-24; paralelo em Lc 11,14-22: o endemoninhado mudo;

- Mt 12,43-45; paralelo em Lc 11,24-26: (um ensinamento da Fonte Q) “o mal está sempre presente).

Além desse material narrativo, há "Ditos do Senhor" em que o tema do exorcismo ocorre, na controvérsia em torno de Belzebu (RABUSKE, 2001, p. 39):

- Mc 3,20-30, paralelo em Mt 12,22-30; 31-37 e em Lc 11,14-15.17-23;12,10;

- Lc 13,32, sem paralelo.

Nos Evangelhos Sinóticos e nos Atos dos Apóstolos, há, por fim, referência à atividade exorcista da parte dos discípulos de Jesus (RABUSKE, 2001, p. 39):

- Mc 3,15; 6,7; 6,13, paralelo em Mt 10,1; 10,8: os discípulos são enviados por Jesus com a tarefa de expulsar demônios e, ao retornarem, comunicam o cumprimento da missão;

- Mc 16,17: retoma-se o exorcismo como sinal dos que crêem em Jesus;

- Mt 7,22: numa cena fictícia de final de mundo, cristãos carismáticos imaginam argumentar que expulsaram demônios em nome de Jesus;

- Mc 9,38-41, paralelo em Lc 9,49s: alguém expulsa demônios em nome de Jesus; 
- At 19,13-16: menção a exorcistas judeus, estranhos ao movimento de Jesus; utilizam-se do nome de Jesus mas fracassam nesse trabalho.

As características das narrativas de exorcismo seguem, em linhas gerais, o seguinte esquema:

- Entrega do indivíduo ao demônio: este toma o lugar do sujeito humano.

- Luta entre demônio e exorcista, em que ambas as partes usam a mesma arma (por exemplo, um saber miraculoso, língua estrangeira, violência). A ausência de rituais de exorcismos é característica nos exorcismos de Jesus, como mostra uma comparação com Josefo (Ant 8,46-48): o exorcista judeu Eleazar lança mão de fórmulas conjuratórias, um anel e uma raiz para expulsar o demônio.

- Atividade destruidora do demônio também fora da pessoa, para entre outras coisas demonstrar sua retirada, conforme a morte da vara de porcos em Mc 5,1Ss (THEISSEN; MERZ, 2002, p. 316-317).

Por fim, vale salientar que as narrativas de exorcismos têm uma estrutura semelhante às narrativas de cura, com a variante de que o encontro com o taumaturgo se transforma numa espécie de embate entre o terapeuta (no caso, exorcista) e um espírito de possessão (demônio), que, por fim, acaba vencido e expulso do possesso. Contudo, a delimitação entre narrativas de curas e exorcismos, em certos casos, não fica bem definida, porque ora se utiliza a expressão "espírito de doença" (Lc 13,10), ora de "endemoninhado cego e mudo" (Mt 12,22; cf. 9,32-34; 17,15.18 par.). Até um gesto poderoso de libertação, como o domínio da tempestade do lago, é descrito como uma espécie de exorcismo, conforme Mc 1,25; 4,39 (FABRIS, 1988, p. 146-147).

\section{Narrativas de curas e exorcismos como expressões da linguagem religiosa}

Os relatos dos Evangelhos em torno das curas e exorcismos expressam uma linguagem própria do mundo de Jesus e das primeiras comunidades cristãs. Os personagens dessas narrativas, bem como os próprios narradores, estão todos mergulhados numa atmosfera religiosa carregada do imaginário da cultura judaica, oral e escrita, incluindo aí toda expectativa messiânica daquele contexto 
escatológico e apocalíptico.

Luigi Schiavo, no artigo "Jesus taumaturgo - Elementos interpretativos", publicado pela RIBLA, n. 47, faz uma excelente síntese daquele contexto histórico, apresentado em três perspectivas: apocalíptica, escatológica e messiânica. $\mathrm{Na}$ perspectiva apocalíptica, destaca-se que o judaísmo daquela época estava marcado pela expectativa da iminente revelação de Deus na história, pondo fim às forças do mal que agiam por meio dos seus agentes, os demônios. A atividade taumatúrgica de Jesus, seus milagres e exorcismos, devem ser lidos dentro desse ambiente de conflito final. Do ponto de vista escatológico, percebe-se a consciência de se estar vivendo os últimos tempos, o que deu origem a vários movimentos radicais na Palestina, tais como: taumaturgos judaicos, profetas escatológicos, movimento zelota, comunidade monástica dos essênios, etc. Na perspectiva messiânica, sobretudo até a primeira metade do século I, observa-se a forte expectativa da chegada do Messias: o agente escatológico da salvação que, por meio de sua práxis, manifestará a intervenção definitiva de Deus em prol do seu povo (2004, p. 83-86).

Nessa linha de análise do contexto histórico, afirma Ivoni Richter Reimer (2008, p. 66) que as narrativas de curas e exorcismos

podem ser interpretadas no plano da significância, que permite uma interpretação na qual interagem dois momentos distintos e interligados da narrativa: a pessoa doente/possessa incorpora e representa a coesão social através de exclusão, a qual indica para a experiência pessoal e social de caos e desequilíbrio; a prática libertadora de Jesus indica para a ruptura com esse esquema através do perdão, da cura, do exorcismo. Assim, conclui-se que a ação de Jesus intervém nas relações sociais e simbólicas de corpos doentes e sofridos, reconstruindo, portanto, também identidades pessoais e sociais.

As ações terapêuticas de Jesus, por meio de suas curas e exorcismos, ganham, então, relevo todo especial dentro desse contexto de significâncias da cultura judaica. O Reino de Deus chegou e instaura-se nas novas relações sociais que estão sendo implementadas na prática de Jesus; corpos doentes são restaurados e mentes conturbadas são apaziguadas... O Reino de Deus chegou e 
instaura-se em pleno contexto do anti-Reino. Essa teria sido, inclusive, a autoconsciência de Jesus a respeito de sua própria missão. Quando interrogado pelos discípulos de João sobre se ele era mesmo "aquele que há de vir", o Messias, Jesus responde categoricamente, narrando suas próprias ações: “Ide contar a João o que ouvis e vedes: os cegos recuperam a vista, os coxos andam, os leprosos são purificados e os surdos ouvem, os mortos ressuscitam e os pobres são evangelizados. E bem-aventurado aquele que não se escandalizar por causa de mim!" (Mt 11,4-5; Lc 7,22-23). Como se percebe, alude-se aqui a passagens do livro do profeta Isaías $(26,19 ; 29,18 \mathrm{~s} ; 35,5 \mathrm{~s} ; 61,1)$. Trata-se de uma linguagem religiosa para afirmar que os tempos da espera profética chegaram ao fim: a prática taumatúrgica de Jesus é sinal da libertação escatológica.

De modo particular, nesse contexto de irrupção do Reino, os exorcismos de Jesus são interpretados como ação libertadora de Deus. Em Lc 11,20 (paralelo com Mt 12,28) é o próprio Jesus que levanta a seguinte hipótese: “... se é pelo dedo de Deus que eu expulso os demônios, então o Reino de Deus já chegou a vós”. O significado é o seguinte: o poder libertador que age em Jesus é o próprio Deus, o “dedo de Deus”, segundo Lucas, o “Espírito de Deus”, segundo Mateus (12,28). É Deus mesmo que derruba as forças contrárias do mal e da morte. "Tudo, porém, aparece aqui limitado ao raio de sua atividade exorcista e, podemos acrescentar, curadora, visto que doença e possessão demoníaca eram fenômenos conexos" (BARBAGLIO, 2011, p. 277-278).

O exorcismo nos Evangelhos, conforme interpreta Ched Myers (1992, p. 183), "é uma das características centrais da ação messiânica de Jesus". Essas narrativas encenam o mito do combate apocalíptico entre os poderes do mal e a pessoa de Jesus, o enviado do Reino. Nesse embate, o Cristo é facilmente identificado pelos demônios (Mc 1,34; 3,11s), enquanto permanece oculto na cabeça confusa de muita gente que segue Jesus de perto (Mc 1,27; 2,12). Esse drama apocalíptico alcançará seu auge na discussão sobre Beelzebu (Mc 3,22s), em que as autoridades dos escribas lançam contra-ataque na guerra de mitos, que atingirá seu 
clímax quando Jesus consegue virar a mesa e extrair de um demônio o seu nome, conforme Mc 5,9: "Legião é o meu nome, porque somos muitos" ("legião" sugere as forças de ocupação romana; uma legião romana constava de seis mil homens). As duas narrativas posteriores de exorcismos, Mc 7,24ss (a expulsão do demônio que dominava a filha da mulher siro-fenícia) e Mc 9,14ss (a expulsão do espírito mudo de um rapaz), também estão ligadas às estruturas de poder e de alienação no mundo social. Na primeira, observa-se o profundo abismo existente entre judeus e gentios; na segunda, percebe-se a luta agonizante para acreditar na nova ordem do Reino (MYERS, 1992, p. 183-184).

Os sinais do Reino transparecem nas narrativas de curas e exorcismos de Jesus como evidentes e visíveis. A esperança, finalmente, tornou-se realidade. Mas, ao mesmo tempo, todos têm a sensação de que está apenas começando... ainda não se realizou em sua completude. Trata-se de um Reino que já está presente, mas ainda não plenamente. Numa linguagem teológica, Jesus de Nazaré "vive intensamente a nossa vida, libera-nos e motiva-nos em esperança para o encontro definitivo, o hoje escatológico, quando Deus será tudo em todos e em todas as coisas" (KUZMA, 2014, p. 212).

Nessa perspectiva, a esperança cristã irradia a expectativa da plenitude dos tempos, fundamentando-se no que já se observa e se experimenta na história, por meio do que Jesus fez e ensinou. Com efeito, Jesus não é somente o Messias da palavra, mas também o Messias da ação. Como afirma Cássio Murilo Dias da Silva (2003, p. 295), “a palavra de Jesus não é apenas plena de sabedoria, mas também plena de poder e eficácia... capaz de subjugar as forças demoníacas e de estabelecer uma realidade nova e libertada”.

Essa compreensão de fé sobre Jesus já estava presente na linguagem religiosa das narrativas de curas e exorcismos. Ele foi compreendido pelos redatores dos Evangelhos como o cumprimento das Sagradas Escrituras... 
e ainda mais, nele expectativas escatológicas míticas foram apresentadas como história: ele personifica o senhorio de Deus. Ele "historiciza" este mito escatológico.... Jesus, no mais breve tempo possível depois de sua morte, foi elevado à condição de divindade. Ele foi venerado como Filho de Deus, Senhor exaltado e Salvador. O tempo de seu surgimento foi envolto com o fulgor místico de um novo tempo de julgamento e sua história foi dramatizada como um confronto entre o Senhor e as potências espirituais míticas por ele subjugados (THEISSEN, 2009, p. 32).

Os relatos de curas e exorcismos da tradição dos Evangelhos expressam, portanto, em linguagem religiosa proveniente da cultura judaica, a fé na pessoa de Jesus como o Messias. Os Evangelhos e, de modo especial o Evangelho de Marcos, põem essas narrativas a serviço da cristologia (GNILKA, 1992, p. 260).

\section{Observações finais}

Narrativas de curas e exorcismos praticadas por homens e mulheres carismáticas não estão circunscritas apenas à cultura dos povos do mundo antigo, tal como o povo de Jesus. Esses relatos podem ser encontrados ao longo dos séculos, em todas as culturas, até hoje, porque pertencem à universal linguagem religiosa do homo religiosus.

A linguagem por meio da qual são narradas as curas e exorcismos deve ser tomada como uma expressão da experiência humana de autossuperação dos limites provocados pelas vulnerabilidades da vida. Por meio dessa linguagem ficam evidentes, pelo menos, três elementos interligados: (1) a derrocada final das forças maléficas por meio de uma energia revitalizadora, dynamis, que provém diretamente de Deus; (2) o papel do taumaturgo que imbuído do dinâmico poder de Deus, serve de ligação entre o humano necessitado e o divino generoso; (3) a fé, palavra que na língua das narrativas bíblicas, o grego, evoca a experiência de "confiança" da pessoa necessitada para como a pessoa do taumaturgo.

Desse modo, narrativas de curas e exorcismos proclamam a realização do milenar desejo humano de uma "terra sem males", que oportuniza a realização da utopia de uma nova sociedade, justa e igualitária, em que todos possam viver com 
saúde, na plenitude de suas potencialidades. Em linguagem religiosa, trata-se do "Reino de Deus”, em que incluídos e, por isso, bem-aventurados serão também as pessoas absolutamente pobres, doentes do corpo e da mente, humilhadas em sua dignidade humana por não poderem sequer trabalhar para prover o próprio sustento; esmagadas até o âmago de si mesmas, esmaecidas em seu espírito, hálito de vida, essência vital, essas pessoas são os "pobres em espirito" da primeira bemaventurança de Mt 5,3.

Concluindo, pode-se perceber, na linguagem religiosa das narrativas de curas e exorcismos, uma denúncia profética e um anúncio escatológico, como duas faces de uma mesma moeda. Por um lado, denunciam o anti-Reino, isto é, os impérios desumanos que se sucedem ao longo da história; eles causam empobrecimento, miséria, sofrimento e encurtamento da vida de "grande multidão", milhares de pessoas marginalizadas em sua própria terra, ou que migram de um lado para o outro, “como ovelhas sem pastor” (expressões usadas na narrativa de Mc 6,34). Por outro lado, as narrativas de curas e exorcismos de Jesus anunciam uma Boa Nova: a chegada do tão esperado fim dos tempos, a plenitude dos tempos, em que Deus, finalmente, intervém em prol da "grande multidão" excluída, por meio do seu Ungido (o Cristo) e de seus adeptos (os cristãos e cristãs). Trata-se de uma prática que interpela cada ser humano a promover a vida com dignidade para todos, reencontrando, desse modo, a vocação de colaborar com Deus em prol da obra da criação, para que a vida aflore em abundância para todos os seres vivos do planeta, nossa casa comum. Essa pode ser interpretada como a grande utopia presente na linguagem religiosa das narrativas de curas e exorcismos de Jesus. 


\section{REFERÊNCIAS}

BARBAGLIO, Giuseppe. Jesus, hebreu da Galileia. Pesquisa história. São Paulo: Paulinas, 2011.

BARTOLOMÉ, Juan José. Resenha da pesquisa crítica sobre os milagres de Jesus. In: AGUIRRE, Rafael (org). Os milagres de Jesus: perspectivas metodológicas plurais. São Paulo: Loyola, 2009. p. 13-50.

BÍBLIA DE JERUSALÉM. Nova edição, revista e ampliada. São Paulo: Paulus, 2002.

CROATTO, José Severino. As linguagens da experiência religiosa: uma introdução à fenomenologia da religião. São Paulo: Paulinas, 2001.

CROSSAN, John Dominic. O Jesus histórico: a vida de um camponês judeu do Mediterrâneo. Rio de Janeiro: Imago, 1994.

FABRIS, Rinaldo. Jesus de Nazaré: História e interpretação. São Paulo: Loyola, 1988.

GNILKA, Joachim. El Evangelio segun San Marcos. I (Mc 1,1 - 8,26). Salamanca:

Sigueme, 1992.

KLAUCK, Hans-Josef. O entorno religioso do cristianismo primitivo I: religião civil e religião doméstica, cultos e mistérios, crença popular. São Paulo: Loyola, 2011.

KUZMA, Cesar. O futuro de Deus na missão da esperança: uma expectativa escatológica. São Paulo: Paulinas, 2014.

LIBÂNIO, João Batista. Deus e os homens: os seus caminhos. Petrópolis: Vozes, 1990.

MAREGUERAT, Daniel; BOURQUIN, Yvan. Para ler as narrativas bíblicas: Iniciação à análise narrativa. São Paulo: Loyola, 2009.

MEIER, John Paul. Um judeu marginal: repensando o Jesus histórico. V. II, Livro 3. Rio de Janeiro: Imago, 1998.

MYERS, Ched. O Evangelho de São Marcos. São Paulo: Paulinas, 1992.

PAGOLA, José Antonio. Jesus: aproximação histórica. São Paulo: Paulinas, 2009.

RABUSKE, Irineu J. Jesus exorcista: Estudo exegético e hermenêutico de Mc 3,20-30. São Paulo: Paulinas, 2001.

REIMER, Ivoni Richter. Milagre das mãos: curas e exorcismos de Jesus em seu contexto histórico-cultural. São Leopoldo: Oikos; Goiânia: UCG, 2008. 
SCARDELAI, Donizete. Movimentos messiânicos no tempo de Jesus: Jesus e outros messias. São Paulo: Paulus, 1998.

SCHIAVO, Luigi. Jesus taumaturgo - Elementos interpretativos. Revista de

Interpretação Bíblica Latino-Americana. Petrópolis, Vozes, v. 47, p. 80-92, 2004/1.

SILVA, Cássío Murilo Dias da. Metodologia de exegese bíblica. 2. ed. São Paulo: Paulinas, 2003.

THEISSEN, Gerd. A religião dos primeiros cristãos: uma teoria do cristianismo primitivo. São Paulo: Loyola, 2002.

THEISSEN, Gerd; MERZ, Annette. O Jesus histórico: um manual. São Paulo: Loyola, 2002.

WEBER, Max. Economia e Sociedade: fundamentos da sociologia compreensiva. Brasília: UNB; São Paulo: Imprensa Oficial, 1999. 